\title{
Determinants of Export Decisions by Manufacturing Firms in Botswana
}

\author{
Kefilwe Sebolao, Lesego Sekwati ${ }^{*}$, Malebogo Bakwena
}

Department of Economics, University of Botswana, Gaborone, Botswana

\author{
Email address: \\ sekwatil@mopipi.ub.bw (L. Sekwati) \\ ${ }^{*}$ Corresponding author
}

\section{To cite this article:}

Kefilwe Sebolao, Lesego Sekwati, Malebogo Bakwena. Determinants of Export Decisions by Manufacturing Firms in Botswana. International Journal of Business and Economics Research. Vol. 8, No. 5, 2019, pp. 257-262. doi: 10.11648/j.ijber.20190805.12

Received: June 11, 2019; Accepted: July 16, 2019; Published: August 5, 2019

\begin{abstract}
The paper examines determinants of export decisions and export intensity by manufacturing firms in Botswana, a developing country in Sub-Saharan Africa. Manufacturing, is one of several sectors through which the government seeks to pursue the all-important diversification of the economy. Botswana's economy is heavily dependent on a diamond sector that in recent years has been declining, and is expected to decline further as diamond resources dwindle. Manufacturing is one of the sectors expected to play an important role in driving the expansion of the economic base. This paper contributes to the debate on policies to promote the growth of the sector. The paper examines factors likely to influence firms decisions to participate in global markets. Global markets provide a higher potential for firms to grow and make a meaningful impact in the economy. The paper applies Probit and Tobit models to firm level data to identify determinants of the decision to export and analyse export intensity respectively. The results of the Probit model show that firm age, firm size, human capital and access to finance increase rge likelihood of entering the export markets. On export intensity, results from the Tobit model show that firm size, human capital and firm location matter. The results suggest that economic gains can be expected from improving access and quality of education. Access to finance, and sea ports. Sector specific policies are also likely to benefit firms in textile and garments and chemicals.
\end{abstract}

Keywords: Export Decision, Export Intensity, Manufacturing Firms

\section{Introduction}

Increasing manufactured exports remains decidedly important for small developing economies such as Botswana. Growth in exports boosts aggregate demand, which is expected to lead to higher economic growth [34]. A rise in exports is also expected to lead to higher productivity and efficiency in exporting firms. Research has also shown that exporting can enhance the growth of labour based sectors, and consequently, their employment generation capacity [17]. Moreover, participation in foreign markets is expected to promote innovation in exporting firms [29].

While the mining sector remains the largest exporter, and contributor to GDP in Botswana, its importance has waned in recent years (see [6]). This is on the back of erratic performance of the global market for diamonds in the last two decades. More worrisome for Botswana, is the fact that diamond production is expected to decline significantly as diamond reserves are drawn down in the coming years, underlining the importance of alternative drivers of growth. The manufacturing sector is one of several identified by the government as a potential driver of growth. While its contribution to GDP has been relatively low (around $6 \%$ on average), the sector has been experiencing steady growth in recent years [15]. This paper contributes to the debate on policies to stimulate the growth and export potential of firms operating in the sector. Specifically, it examines determinants of export decision by manufacturing firms. It also examines determinants of export intensity for these firms.

The paper applies Probit and Tobit models to firm level data on manufacturing firms in Botswana. The Probit model is used in the analysis of determinants of export decision, while the Tobit model is used in the analysis of export intensity. Results show that firm age, firm size, and human capital and financial constraints matter in the decision to export, while firm size, human capital and sector specific 
characteristics matter for export intensity.

\section{Determinants of Export Decision and Intensity: A Review}

A number of studies have shown that the decision by a firm to export may be influenced by its characteristics as well as the business environment. These factors have also been found to influence export intensity for exporting firms. There is no uniformity in the findings however, underlining the importance of country specific studies such as this one. A huge body of this literature exists. This section reviews this literature. For the sake of brevity, attention is restricted to the literature on firm specific characteristics and business environment considered in this paper. The paper builds on the literature.

\subsection{Firm Characteristics and the Decision to Export and Export Intensity}

Firm specific characteristics provide leverage for a firm to generate value to be in a favorable business position in foreign markets. They include firm age, firm size, ownership structure, and expenditure on research and development $[1,7$, 21, 27, 31].

Firm age: According to [1], the period a firm has been operating in an industry may be interpreted as indicative of the time it has had to establish and grow operations and distribution networks. In addition, a firm which has been in an industry for a long time may benefit from knowledge accumulated overtime. [1, 21, 31] found evidence that firm age has a positive and significant impact on the decision to export and on export intensity. In contrast, [23] found that younger firms found it easier to enter export markets as they are more aggressive, flexible and prepared to grasp new opportunities. In addition, they are often ready to take risks with new technologies, which are likely to be more efficient.

Firm size: Firm size is viewed as a proxy for exploiting scale economies. The variable has been shown to contribute significantly to increasing the probability of firms entering the export market [10]. At the heart of the debate is that small firms operate at a level too small to sufficiently exhaust economies of scale. According to the study [18], if firms are not exploiting economies of scale, they are not taking advantage of relative savings on inputs that can be achieved from operating at or close to the minimum efficient scale. This means that production costs are higher for firms that are not exploiting economies of scale [33, 7]. However, it is argued that large firms may not participate in international markets for a long time because they are dominated by bureaucratic bottlenecks which are likely to hinder innovation [11]. Therefore, while they may find it easy to enter foreign markets, they may find it difficult to stay in the market for long.

Ownership structure: Ownership structure reflects the percentage of the business with foreign interests. It is argued that firms with foreign equity participation benefit from greater management experience and superior organizational structure and are therefore more likely to participate in foreign markets. According to the research [11], foreign owned firms may also have access to proprietary information and special right of entry to distribution channels which gives them additional benefits over domestic owned firms. These extra benefits provide foreign owned firms with an advantage to lower entry costs. In addition, access to proprietary information and special right of entry to distribution channels may contribute to high productivity and lower costs for foreign firms. Therefore, foreign owned firms self- select into foreign markets [8]. Evidence that foreign owned firms are more likely to enter foreign markets, and are likely to export more, can be found in [5, 11, 21, 31].

Research and Development $(R \& D)$ : $R \& D$ expenditure is often used as a proxy for innovation. Innovative firms are thought to be more likely to be competitive in global markets, and therefore likely enter export markets. Exporting also allows firms to optimize returns on their investment on innovation. A positive relationship is thus expected between intensity of R\&D and the decision to export. In fact, in North Africa, innovative and marketing aspects do not improve SMEs' export propensity unless decision makers are export oriented, experienced and skilled in export matters [16]. Not many studies have investigated this relationship. This paper adds to the limited empirical evidence on the relationship.

\subsection{The Business Environment and the Decision to Export and Export Intensity}

The business environment may act as a barrier or stimuli for export status, including export intensity. They act as stimuli if they cause or encourage firms to enter export markets (or increase the volume of exports) or as a barrier if they obstruct firms from exporting. These factors include government policies e.g. export subsidies and Special Economic Zones (SEZ), access to finance, access to, and quality of infrastructure etc.

Access to finance: According to [20], access to finance reduces liquidity and credit constraints which in turn provides a firm the resources to compete in foreign markets.. The ease of accessing finance is linked with well-functioning and efficient markets that provide incentives such as external finance which may allow firms to undertake decisions on projects that are risky but have high returns such as exporting [5]. [13] found that firms that can easily access financial services are likely to enter foreign markets. Financial resources also put firms in a position to export intensively.

Export subsidies: Manufacturing firms often face barriers which constrain them from creating well established distribution channels that could assist them enter export markets [31]. Export subsidies are normally implemented to assist firms deal with such problems. However, export subsidies are not always successful [8]. [28] found that export subsidies did not influence the decision of firms to export.

Special Economic Zones (SEZ): Special Economic Zones serve as instruments that promote large scale operations and 
attract foreign investors, which may influence firms positively to participate in foreign markets [12]. Firms in Special Economic Zones are expected to benefit from tax holidays, subsidized loans or grants, and favourable business environment. Firms are also expected to benefit from spillover effects of clustering. [3, 7, 19, 24], find evidence that Special Economic Zones can make a difference. [2] find evidence to the contrary.

Human capital: According to [7], human capital approximates the the ability of a firm to absorb new knowledge and technologies. A firm with a high proportion of skilled workers is thus expected to be highly likely to enter foreign markets. They found evidence that a high proportion of skilled labour contributes to innovation, development and productivity of a firm which may increase the chance of a firm entering foreign markets. Finally, often used as a proxy for transport costs associated with exporting, proximity to sea ports, railway lines and tarred roads is also expected to have an impact on the decision to export.

From the preceding review, it is quite clear that there is no regularity on the findings regarding the impact of different factors on export decision and export intensity. This underlines the importance of carrying out country specific studies such as the current one, to avoid erroneous policy prescriptions.

\section{Methodology}

\subsection{Introduction}

A Probit model is used to analyze determinants of export decision by manufacturing firms in the sample, while a Tobit model is used to analyze determinants of export intensity.

The Probit model takes the form:

$$
\begin{gathered}
Y_{i}^{*}=\beta X_{i}+\mu_{i} i=1,2, \ldots, n \\
Y_{i}=1 \text { if } Y_{i}^{*}>0 \\
Y_{i}=0 \text { otherwise }
\end{gathered}
$$

Where: $\mathrm{Y}_{i}$, the dependent variable measures export status. An exporting firm takes the value 1 whilst the non-exporting firm takes value 0 . The model assumes that the value of export status, is determined by a latent, unobserved variable $\mathrm{Y}^{*}$ of the $i^{t h}$ firm. When the value of latent variable is large, there is high chance that the firm will make a decision to export. $X_{i}$ represents vector of explanatory variables; $\beta$ represents parameters to be estimated; and $\mu$ represents disturbance term.

Once the determinants of firm's export decision have been established, a Tobit model is used to find out what determines the level of exports for exporting firms. The Tobit model is observed only for a particular sample in which information on the dependent variable is known hence identified as censored regression model. The Tobit model assumes that any variable that leads to a decision to export, must also influence the output level of exporting firms. Thus, any variable that increases the probability of a firm exporting may also increase the average volume of exports of the exporting firms.

\subsection{Determinants of Export Decision}

To analyze determinants of export decision, model (1) is estimated:

$$
\begin{aligned}
Y_{i}^{*}= & \beta_{1} \log _{A G E}+\beta_{2} \log _{A G E} 2+\beta_{3} O S+\beta_{4} H M+\beta_{5} L+ \\
& \beta_{6} \log _{F S}+\beta_{7} F A+\beta_{8} T D+\beta_{9} R D+\mu_{i}
\end{aligned}
$$

Where: $\log _{\mathrm{AGE}}=$ logarithm of a firm's age; LogAGE2 = square of the logarithmic of firm's age; OS = ownership structure (dummy variable: foreign owned firms $=1,0$ otherwise); Log FS = logarithm of firm size; RD = Research and Development (dmmy variable: 1 for firms owning patent and rights in any technology, 0 otherwise); L = Location (dummy variable: 1 for a firm in a major city); FA = financial access (dummy variable: 1 for firms finding it difficult to access financial services); TD $=$ trade development (dummy variable: 1 for firms within a special economic zones, 0 otherwise); and HM = human capital (skilled employees).

The model is estimated using maximum likelihood estimation (MLE). This technique permits computation of estimates of coefficients of the variables and their corresponding standard errors [14]. The magnitude and signs of the coefficients show the impact of explanatory variables on the decision to export. Estimates are computed using STATA.

\subsection{Determinants of Export Intensity}

To analyze determinants of export intensity, model (2) is estimated:

$$
\begin{array}{r}
X_{i j}=\beta_{0}+\beta_{1} \log _{A G E}+\beta_{2} \log A G E^{2}+\beta_{3} O S+ \\
\beta_{4} S P+\beta_{5} L+\beta_{6} \log _{F S}+\beta_{7} F A+\beta_{8} T D+\beta_{9} R D+ \\
+\beta_{10} C H+\beta_{11} T G+\mu_{i}
\end{array}
$$

All variables are as previously definined except for the following: $\mathrm{CH}$; $\mathrm{TG}$; and ME. These are added to account for sector specific characteristics.

$\mathrm{CH}$ (dummy variable for chemicals sector: 1 for firms in the chemicals sector, 0 otherwise): Manufacturing of chemical products involves processing that heavily relies on innovation and technology and this technology is protected with patents and copyrights which are expensive to buy. Even if a firm owns particular patents and technology, technology should be improved constantly to produce products that are competitive and attractive in foreign markets. This toughens competition in foreign markets especially for firms that do not own patents and copyrights or invest regularly in technology to improve quality of their products.

TG (dummy variable for Textile and garments: 1 for firms under the Textile and garments sector: This sector receives major support from Botswana trade policies because of its high employment elasticity and also its ability to employ semi- skilled personnel and females [9]. The sector has benefited from large foreign markets such as United States, European market through Africa Growth and Opportunity 
Act [30]. It also benefits from free trade in Southern African Customs Union [30]. Moreover, products are easy to transport due to their manageable weight which means that the transportation costs should be lower than heavy products from other industries such as machinery.

The Tobit model estimates how dependent variable changes when independent variables change. The model assumes that any variable that increases the probability of a firm to export should also increase the average volume of exports of the exporting firms.

\subsection{Data}

This paper uses data from the World Bank Enterprise Survey (WBES) on Botswana [35]. The data captures firm specific characteristics and business environment factors for manufacturing firms in Botswana. The survey included a sample of 116 manufacturing firms. Based on data considerations, only 87 of these firms were included in the analysis.

\section{Estimation Results}

This section presents the findings of the empirical analyses. Table 1 presents summary statistics of the variables included in the analyses. The standard deviations for some of the variables e.g. machinery and equipment, textile and garments, chemicals, technology, finance, ownership structure are larger than their means, indicating a wide spread of the data from their means. Standard deviations for other variables e.g. firm age, firm size, location and skilled labour are smaller than their means.

Table 1. Summary statistics of variables used in the analysis.

\begin{tabular}{llll}
\hline Variable & Mean & Standard deviation & Observations \\
\hline Firm age & 3.104 & 0.455 & 87 \\
Firm size & 3.472 & 1.063 & 87 \\
$\begin{array}{l}\text { Ownership } \\
\text { structure }\end{array}$ & 0.459 & 0.501 & 87 \\
Location & 0.839 & 0.369 & 87 \\
Human capital & 87.78 & 31.49 & 87 \\
$\begin{array}{l}\text { Finance access } \\
\text { Research and }\end{array}$ & 7.620 & 9.631 & 87 \\
$\begin{array}{l}\text { development } \\
\text { Trade development } \\
\text { (proxy for SEZ) }\end{array}$ & 0.034 & 0.183 & 87 \\
$\begin{array}{l}\text { Chemicals } \\
\text { Textile and }\end{array}$ & 0.0132 & 1.854 & 87 \\
garments & 0.218 & 0.273 & 87 \\
\hline
\end{tabular}

Source: Authors computations based on WBES (see [35])

\subsection{Analysis of Determinants of Export Decision}

Results are summarized in Tables 2 and 3 . Table 2 summarises results of the analysis of determinants of export decision. Table 3 summarises partial effects of the Probit model. Table 2 reveals that estimates are jointly statistically significant with a chi-square value of 36.99 and p-value of 0.000 . They also show the model has a good fit, with pseudo R-square of 0.7890 . As expected, firm age and firm size both have a positive and significant impact on the decision to export. The results are consistent with [4, 22, 26]. Human capital is also estimated to have a positive and significant impact on the decision to export. As expected, difficulty in accessing finace is estimated to have a significant and negative impact on the decision to export. The result is consistent with $[25,26]$. Table 3 reveals that firm age increases probability to export by 13 percent. Moreover, size effects increase the probability of a firm to export by 5 percent, while human capital effects increase the probability to export by 0.17 percent. Difficulty in accessing fincance reduces probability of exporting by 0.07 percent.

Table 2. Determinants of Export Decision.

\begin{tabular}{llll}
\hline Variable & Coefficient & $\mathbf{Z}$ & $\mathbf{P}>\mathbf{Z}$ \\
\hline Constant & -211.319 & -0.25 & 0.802 \\
Log (age) & 2.7820 & 1.72 & $0.086^{*}$ \\
Log (age squared) & 27.0133 & 0.24 & 0.807 \\
Foreign ownership & 1.0649 & 1.11 & 0.267 \\
Location & 0.0511 & 0.05 & 0.960 \\
Log (size) & 1.0787 & 2.52 & $0.012^{* *}$ \\
Research and development & 2.7186 & 0.91 & 0.361 \\
Financial access & -0.465 & -2.27 & $0.023^{* *}$ \\
Human capital & 0.1129 & 1.75 & $0.081^{*}$ \\
Trade development & 0.2541 & 2.53 & 0.234 \\
Log likelihood $=-6.3544199$ & & & \\
Number of obs $=87$ & & & \\
LR chi2 $(8)=35.99$ & & & \\
Prob $>$ chi2 $=0.000$ & & & \\
Pseudo R2 $=0.7890$ & & & \\
\hline
\end{tabular}

Source: Authors computations based on WBES (see 35)

$* * *, * *$ and $*$ indicate statistical significance at the $1 \%, 5 \%$, and $10 \%$ levels, respectively. Dependent variable: Export dummy, exporting firms take value 1

Table 3. Partial Effects for the Probit model.

\begin{tabular}{llll}
\hline Variable & $\mathbf{d y} / \mathbf{d x}$ & $\mathbf{Z}$ & $\mathbf{P}>\mathbf{Z}$ \\
\hline Log (age) & 0.1253 & 1.96 & $0.049^{* *}$ \\
Log (age squared) & 1.5856 & 5.34 & 0.524 \\
Foreign ownership & 0.0446 & 0.82 & 0.415 \\
Location & -0.0070 & -0.09 & 0.927 \\
Log (size) & 0.0519 & 2.76 & $0.006^{* * *}$ \\
Research and development & 0.0732 & 0.64 & 0.524 \\
Financial access & -0.0007 & -0.03 & 0.975 \\
Human capital & 0.0017 & 3.30 & $0.001^{* * *}$ \\
Trade development & 0.7421 & 2.88 & 0.854 \\
\hline
\end{tabular}

Source: Authors computations based on WBES (see 35)

$* * *, * *$ and $*$ indicate statistical significance at the $1 \%, 5 \%$, and $10 \%$ levels, respectively. Dependent variable: Export dummy. The variable takes a value of 1 for exporting firms.

\subsection{Analysis of Determinants of Export Intensity}

Results of the analysis are summarized in Tables 4 and 5 . Table 4 summarizes results of the analysis of determinants of export intensity. Table 5 summarizes partial effects of the Tobit model. Table 4 reveals that firm size has a positive and significant impact on export intensity. A similar relationship is estimated for human capital. Location is estimated to have a significant, but negative impact on export intensity. This result is consistent with [2]. The result could be because Botswana landlocked, hence disadvantaged due to lack of 
access sea ports. Related to this point, the literature (e.g. the study [32] show that border-related delays may hinder export development. Sector effects are also estimated to be significant and positive for Textile and Garments and Chemicals.

Table 4. Determinants of Export Intensity (Tobit Estimates).

\begin{tabular}{llll}
\hline Variable & Coefficient & T & P>t \\
\hline Constant & 154.897 & 0.02 & 0.987 \\
Log (age) & 15.8263 & 1.19 & 0.240 \\
Log (age squared) & -22.1943 & -0.02 & 0.986 \\
Foreign ownership & -16.8877 & -1.27 & 0.206 \\
Location & -29.1951 & -1.82 & $0.073^{*}$ \\
Log (size) & 15.6463 & 3.18 & $0.002^{* * *}$ \\
Research and development & 22.8273 & 0.86 & 0.392 \\
Financial access & 3.3076 & 0.63 & 0.530 \\
Trade development & 19.587 & 0.75 & 0.911 \\
Human capital & 1.8411 & -5.61 & $0.000^{* * *}$ \\
Chemicals & 38.4211 & 2.12 & $0.037^{* *}$ \\
Textile and garments & 34.2157 & 2.58 & $0.012^{* *}$ \\
Log likelihood $=-80.699469$ & & & \\
Number of obs $=87$ & & & \\
LR chi2 $(8)=58.74$ & & & \\
Prob $>$ chi2 $=0.000$ & & & \\
Pseudo R2 $=0.2668$ & & & \\
\hline
\end{tabular}

Source: Authors computations based on WBES (see [35])

$* * *, * *$ and * indicate statistical significance at the $1 \%, 5 \%$, and $10 \%$ levels, respectively. Dependent variable: Export sales ratio (exports/total sales)

Table 5. Partial Effects for the Tobit model.

\begin{tabular}{|c|c|c|c|c|}
\hline Variable & $d y / d x$ & $\mathbf{Z}$ & $\mathbf{P}>\mathbf{Z}$ & $\mathbf{X}$ \\
\hline Log (age) & 15.8263 & 1.19 & 0.236 & 0.2873 \\
\hline $\begin{array}{l}\text { Log (age } \\
\text { squared) }\end{array}$ & -22.1943 & -0.02 & 0.986 & 7.5978 \\
\hline $\begin{array}{l}\text { Foreign } \\
\text { ownership }^{\wedge}\end{array}$ & -16.8877 & -1.27 & 0.203 & 0.4598 \\
\hline Location^ ${ }^{\wedge}$ & -29.1951 & -1.82 & 0.069 & 0.8391 \\
\hline Log (size) & 15.6463 & 3.18 & 0.001 & 0.3472 \\
\hline $\begin{array}{l}\text { Research and } \\
\text { development }{ }^{\wedge}\end{array}$ & 22.8273 & 0.86 & 0.390 & $0.0344^{* *}$ \\
\hline $\begin{array}{l}\text { Trade } \\
\text { development }\end{array}$ & 16.882 & 3.87 & 0.875 & 0.795 \\
\hline Financial access & 3.3076 & 0.63 & 0.528 & 2.3218 \\
\hline Human capital & -0.8411 & 3.18 & 0.000 & 87.724 \\
\hline Chemicals $^{\wedge}$ & 38.4211 & 2.12 & 0.034 & $0.0804^{*}$ \\
\hline $\begin{array}{l}\text { Textile and } \\
\text { garments }\end{array}$ & 34.2157 & 2.58 & 0.010 & 0.2184 \\
\hline
\end{tabular}

Source: Authors computations based on WBES (see [35])

$* * *, * *$ and * indicate statistical significance at the $1 \%, 5 \%$, and $10 \%$ levels, respectively. $\left({ }^{\wedge}\right) \mathrm{dy} / \mathrm{dx}$ is for discrete change of dummy variable from 0 to 1. $\mathrm{X}$ is Marginal effects of variables at their means. Dependent variable: Export sales ratio (exports/ total sales)

\section{Summary and Conclusions}

The objective of this paper was to analyze determinants of export decision and intensity by manufacturing firms in Botswana. The paper relied on firm level data from the World Bank Enterpise Survey on Botswana [35]. A Probit model was used to analyse determinants of export decision, and a Tobit model was used to analyse determinants of export intensity.

Results of the Probit model revealed that firm age and firm size matter in the decision to export. Human capital was also found to be an important factor in the decision to export, underlining the importance of policies aimed at improving not only access to, but the quality of education and training of the labour force. Difficulty in accessing finance was also found to be important. The result suggests the need for design of policies to ease access to finance for manufacturing firms. These include but not limited to, encouraging competition in the banking sector, establishing a centralised institution that compiles credit history and ratings of businesses with a view to reducing information asymmetry, strengthening property rights protection and bankruptcy laws, and liberalising listing requirements and administrative burdens relating to raising finance through the Botswana Stock Exchange (BSE).

Results of the Tobit model revealed that firm size is an important factor. A result that reinforces the need for improved access to, and quality of education, is the estimated impact of human capital on export intensity. Human capital was found to be an important factor in explaining export intensity. Location was also found to be important. The estimated relationship suggests the need for the country, through existing and new trade agreements, to negotiate cheaper access to ports for manufacturing firms in Botswana. Sector specific caharacteristics were also found to be significant suggesting that sector specific policies are likely to yield economic gains.

\section{References}

[1] Aggrey, N, Eliab, L and Joseph, S. 2010. Firm size and technical efficiency in East African manufacturing firms, Current Research Journal of Economic Theory, (2), 2: 69-75.

[2] Aitken, B., Hanson, G. H and Harrison, A. E. 1997, Spillovers, foreign investment, and export behavior, Journal of International Economics, (43): 103-132.

[3] Amakom, U. 2012. Manufactured exports in sub-saharan African economies: econometric tests for the learning by exporting hypothesis, Ameriacan international journal of contemporary research, (2), 4: 195-206.

[4] Arkes, H and Blumer, C. 1985. The Psychology of Sunk Cost. Organizational Behaviour and Human Decision Processes. (35): 124-140.

[5] Baldwin, R. 1989. On the Growth Effects of 1992. NBER Working Paper \#3119, National Bureau of Economic Research, Cambridge.

[6] Bank of Botswana. 2016. Annual Report 2014, Bank of Botswaba, Gaborone, Botswana.

[7] Bernard, A. B and Wagner, J. 2001. Export Entry and Exit by German Firms, Weltwirtschaftliches Archiv, 13 (1): 13457.

[8] Bhagwati, J and Panagariya, A. 1996. The Theory of Preferential Trade Agreements: Historical Evolution and Current Trends, American Economic Review, 86 (2): 82-87. 
[9] Botswana Investment and Trade Centre. 2014. Annual Report 2014. Botswana Investment and Trade Centre, Gaborone, Botswana.

[10] Chawla, I. 2019. Determinants of firm's Initial decision to Invest Abroad: An Application of "survival" Analysis to Manufacturing Firms in India, Emerging Markets Finance and Trade, 55: 562-583.

[11] Clarke, G. 2005. Beyond Tariffs and Quotas: Why don't African Manufactures Export, World Bank Policy Research Working Paper 3617, World Bank.

[12] Farole, T. 2015. Special economic zones in Africa: comparing performance and learning from global experience, World Bank Group.

[13] Greenaway, D., Guariglia, A and Kneller, R. 2007. Financial factors and exporting decision, University of Nottinghamn.

[14] Greene, W. H. 2012. Econometric Analysis, New York University.

[15] Grynberg, R. Sengwaketse, M and Motswapong, M. 2015. Botswana after Diamonds: A study into the Consequences and Responses to the Depletion of Botswana's Diamonds, Botswana Institute for Development Policy Analysis (BIDPA), Gaborone, Botswana.

[16] Haddoud, M., Beynon, M., Jones, P. and Newbery, R. (2017), SMEs'Export Propensity in North Africa: A Fuzzy c-means Cluster Analysis, Journal of Small Business and Enterprise Development, 25 (5): 769-790.

[17] Harris, R and Cher Li, Q. 2011. Export-market dynamics and firm-level Productivity: evidence for UK tradable sectors, Industrial and Corporate Change, (21), 3: 649-670.

[18] Hill, H and Kalirajan, P (1993), Small enterprise and firmlevel technical efficiency in the Indonesian garment industry, Applied Economics, 25, (9): 1137-1144.

[19] Khandelwa, A and Teachout, M. 2016. IGC Policy Note: Special Economic Zones for Myanmar. Columbia University.

[20] Kumarasamy, D and Singh, P. 2016. Does access to finance facilitates the firm's ability to export? Experience from AsiaPacific countries. ARTNeT Working Paper Series, No. 159, Asia-Pacific Research and Training Network on Trade (ARTNeT), Bangkok.

[21] Manez, J. A., Rochina, M. E and Sanchis, J. A. 2004. The decision to export: a panel data analysis for Spanish manufacturing, Applied Economics Letters, (11), 11: 669-673.
[22] Melitz, M. J. 2003. The Impact of Trade on Intra-Industry Reallocations and Aggregate Industry Productivity, Econometrica, (71), 6: 1695-1725.

[23] Merino, F. and Salas, V. 2000. The relationship between firmspecific assets and intenationalisation in Spanish manufacturers, Documento de Trabajo de la Fundacio'n Empresa Publica P. I. E. 0001.

[24] Moriyama, K. 2010. The spillover effects of the global crisis on economic activity in MENA emerging market countries an analysis using the financial stress index, International Monetary Fund, Working paper \# 10.

[25] Nesterenko, A. 2003. The Determinants of Firms' Export Behaviour. Unpublished Master of Arts degree Thesis, National University of Kyiv-Mohyla Academy, Ukraine.

[26] Niringiye, A and Tuyiragize, R. 2010. Determinants of a Firm's Level of Exports: Evidence from Manufacturing Firms in Uganda, AERC Research Paper 196, African Economic Research Consortium, Nairobi.

[27] Pakes, A. and Ericson, R. 1998. Empirical implications of alternative models of firm dynamics, Journal of Economic Theory, 79: 1-45.

[28] Rankin, N., Soderbom, M and Teal, F. 2005. Exporting from manufacturing firms in Sub-Saharan Africa, GPRG-WPS-036, Global Poverty Research Group.

[29] Sinani, E. \& Bersant Hobdar. 2010. Export market participation with sunk costs and firm heterogenity. Applied Economics, (42), 25: 3195-3207.

[30] Southern African Development Committee (SADC). 2008. Protocol on gender and development.

[31] Srinivasan, T. N and Archana, V. 2011. Determinants of Export Decision of Firms, Economic and Political Weekly, (46), 7: 49-58.

[32] Vijil, M., Wagner, L. and WoldeMichael, M. (2019), Import Uncertainty and Export Dynamics, Policy Research Working Paper \# 8793, World Bank Group.

[33] Wagner, J. 1995. Exports, firm size, and firm dynamics. Small Business Economics, (7), 1:29-39.

[34] World Bank. 2013. Botswana Social Protection Assessment, Human Development Department, Social Protection Unit, Africa Region.

[35] World Bank. 2011. Enterprise Survey, Botswana. World Bank. 